\title{
Utopian Movements: Nikki Giovanni and the Convocation Following the Virginia Tech Massacre
}

\section{Citation}

Bernstein, Robin. 2012. “Utopian Movements: Nikki Giovanni and the Convocation Following the Virginia Tech Massacre." African American Review 45, no. 3: 341-353.

\section{Permanent link}

http://nrs.harvard.edu/urn-3:HUL.InstRepos:12967683

\section{Terms of Use}

This article was downloaded from Harvard University's DASH repository, and is made available under the terms and conditions applicable to Other Posted Material, as set forth at http:// nrs.harvard.edu/urn-3:HUL.InstRepos:dash.current.terms-of-use\#LAA

\section{Share Your Story}

The Harvard community has made this article openly available.

Please share how this access benefits you. Submit a story.

\section{Accessibility}




\section{PROJECT MUSE}

\section{Utopian Movements: Nikki Giovanni and the Convocation Following the Virginia Tech Massacre}

Robin Bernstein

African American Review, Volume 45, Number 3, Fall 2012, pp. 341-353 (Article)

Published by The Johns Hopkins University Press

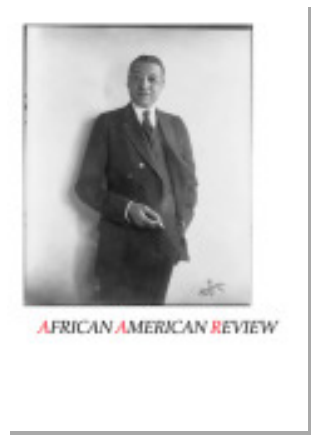

$\Rightarrow$ For additional information about this article http://muse.jhu.edu/journals/afa/summary/v045/45.3.bernstein.html 


\section{Utopian Movements: Nikki Giovanni and the Convocation Following the Virginia Tech Massacre}

Each act, gesture, and movement is political. —Addison Gayle, Jr., The Way of the New World (1975)

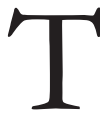
he scenario seems implausible: in a rural sports arena, over ten thousand people of every stripe listen to a poem written by a black feminist, who recites it while wearing a tie and a suit with a masculine cut. Upon the conclusion of the woman's poem, the entire audience rise to their feet and cheer. The President of the United States is in the first row, and he too stands and cheers. Then, the audience mirrors the poet's defining action: acting in unison, the members of the audience spontaneously create and perform a poem, chanting it over and over.

This sequence of unlikely, even utopian events occurred on April 17, 2007 at the Convocation following the "Virginia Tech Massacre," in which student Seung-Hui Cho fatally gunned down thirty-two students and faculty members before ending his own life. ${ }^{1}$ Nikki Giovanni, a luminary of the Black Arts Movement and a professor at Virginia Tech who had personally confronted Cho in the semesters before the shooting, read her poem "We Are Virginia Tech" to the over-capacity audience in Cassell Coliseum, which seats 10,052. At the poem's conclusion, the full house, including then-President George W. Bush, rose cheering and chanted, "Let's Go, Hokies!" In this context, the familiar sports chant "took on new meaning," as one local newspaper noted. The chant became a poem. And the audience members became poets, performing in alliance with a black feminist poet. ${ }^{2}$

These events became possible, this essay argues, because of the confluence of three factors: Giovanni's contribution to and inheritance from the Black Arts Movement (BAM), the physical space of the Coliseum, and finally, the interplay between what Giovanni said and showed and what she temporarily silenced and covered. By integrating these three elements, Giovanni coordinated a utopian performative (to use Jill Dolan's term) that was not felt or imagined as an idealized futurity but instead enacted in the present through collective bodily movement. The distinction between a utopia that is felt or imagined and one that is enacted through collective movement is important, I argue, because the latter solves key problems confronted both by the BAM forty years ago, and by performance scholars today. And with this movement-based utopian performance in the Cassell Coliseum, a queerly dressed poet not only united the Virginia Tech campus in its moment of crisis, but also triumphed over the President of the United States.

\section{Terrors}

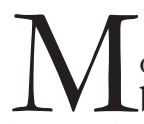
ost mass murderers in the United States have been white men who have been privileged to remain racially unmarked. Seung-Hui Cho, however, was instantly and overwhelmingly defined in the media by his race and national origins. Lucinda Roy, then chair of the department of English at Virginia Tech, argued that persistent mention of Cho's "ethnicity ... suggested that it could be construed as 
a clue to his perverse behavior, or as something we needed to purge" (Roy 262). SuChin Pak, a writer for MTV.com, noted similarly that the persistent description of Cho as a "Korean national" suggested that "somehow Cho's place of birth, his immigrant status, has something to do with the massacre" (qtd. in Roy 261). Roy described racism immediately following the shooting as "potentially explosive" because "it was fed both by those intent upon promoting racial tension, and by those who failed to understand that continually identifying a killer in terms of his ethnicity could lead people to conclude that all those of Asian descent were suspect" (Roy 261-62). In response to these dangers, the Asian American Journalists Association (AAJA) issued a statement:

As coverage of the Virginia Tech shooting continues to unfold, the AAJA urges all media to avoid using racial identifiers unless there is a compelling or germane reason. . . The effect of mentioning race can be powerfully harmful. It can subject people to unfair treatment based simply on skin color and heritage. (qtd. in Roy 260-61)

But as Roy notes, this "plea went largely unheeded" (261). Lyu Boaz, a Korean American student at Virginia Tech, told the New York Times that his parents, fearing hate crimes, had asked him to leave campus and that "parents of other KoreanAmerican students were preparing to pick up their children ... and take them home" (Dewan and Broder). Such fears were warranted: soon after the shooting, Asian and Asian American students at Virginia Tech "reported random incidents" presumably perpetrated by students of non-Asian descent- "of name-calling, threat-making, and even occasional fist-throwing against them" (Luke 14).

When Nikki Giovanni stepped onto the floor of the Cassell Coliseum the day after the shooting, then, the atmosphere was not only one of shock and grief but also one of ongoing terror. The possibility of xenophobic, racist violence overwhelming the Virginia Tech campus was utterly real and terrifyingly palpable.

The poet who took the stage at this precarious moment knew Cho well. As a student in Giovanni's creative writing class, Cho had written violent and sexually aggressive poetry, refused to speak or to remove his hat and sunglasses, and surreptitiously photographed women's legs from below his desk. Giovanni assessed Cho as "an evil presence" and demanded that he withdraw from the class (Macy). When Cho refused, Lucinda Roy agreed to tutor him individually in her office. Roy, like Giovanni, considered Cho a serious physical threat: during the tutoring sessions, Roy's assistant always remained close by and alert, ready to call campus security if Roy uttered a prearranged code word (Fernandez and Santora). When Giovanni first heard on the radio that a then-unidentified Virginia Tech student had killed thirty-two people, she immediately intuited that the shooter was Cho. "Ginney," she said to Virginia Fowler, Giovanni's longtime partner and colleague in Virginia Tech's department of English, "I know who did this" (Macy). Giovanni, an antiracist activist who by 2007 had published more than a dozen volumes of poetry and had cut ten spoken-word albums devoted to black experience and politics, and who was then the winner of three NAACP Image Awards (she has since won two more), could not have been unaware of the racism and xenophobia that imperiled the Virginia Tech community in which she had taught since 1987.

Giovanni wrote the poem "We Are Virginia Tech" in one sitting on the night of the shooting for performance at the Convocation the following day. Giovanni was initially dissatisfied with her poem, which she then considered "pedestrian." She went to bed with hopes of rewriting in the morning, but when morning came, she revised only by crossing out one line. She put on her favorite black suit and tie, diamond-stud earrings she had inherited from her mother, and a large rhinestone pin that read HOKIES, the term for Virginia Tech's athletic teams and campus community. But she did not approach the floor of the Coliseum full of confidence. She was terrified (Macy). 


\title{
Movements
}

\section{$\mathrm{M}$ onths later, when a reporter asked Nikki Giovanni about the experience of writing "We Are Virginia Tech," Giovanni replied that she understood her task in terms of movement:}

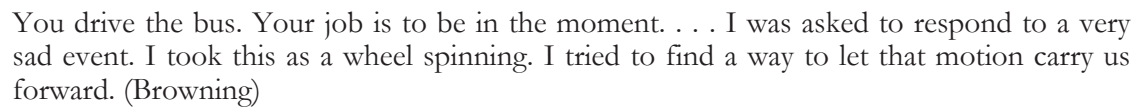
sad event. I took this as a wheel spinning. I tried to find a way to let that motion carry us forward. (Browning)

In Giovanni's view, then, her charge was to harness the energy of a wheel in motiona community reeling from tragedy and potentially careening toward racist violenceand to redirect that energy toward a better future.

This perspective has deep, but often overlooked roots in the Black Arts Movement. Many artists and scholars have argued that the BAM called upon black people to unite through shared political goals based on a universal, stable black identity (a venture that "could not hold," as Amiri Baraka later wrote, because "Black' is not an ideology" but a "reductionist label") (xviii). In fact, however, the demand for unification based on a stable black identity co-emerged with the opposite impulse: a theory of black politics and aesthetics as based in and powered by motion, of black arts as movement in the most literal sense.

The close coexistence of both these visions appears in the 1968 essay "Black Cultural Nationalism." In this essay, Ron Karenga articulated the demand for unification even as he denied it: there "can be and is unity in diversity," Karenga wrote, "even as there can be diversity in unity" (36). Here, even as Karenga allowed for diversity and claimed that diversity need not prevent unity, he positioned diversity as unity's detractor, as a potential if not inherent threat. Only a few sentences later, however, Karenga reimagined the relationship between unity and diversity in terms of movement, both musical and physical:

\begin{abstract}
In a Trippin [jazz] ensemble the "leader" sets the pace and others come in, or go out, as it pleases them, but in the end they all come to a very dynamic and overwhelmingly harmonious conclusion. So it is with our dance-two partners dance together the same dance and yet they provide us with a demonstration of that which is unique in each of them. . . For it is an expression of uniqueness, not isolation from, but in relation to, each other and the collective experience that they both have shared. (Karenga 36)
\end{abstract}

This passage could of course be understood simply as metaphor. But Karenga was using art-music and dance-to describe and champion black collective art in general. The example of dancing or ensembling music, then, seems to be more metonym than metaphor. The BAM's "black aesthetic"-both the concept and Addison Gayle, Jr.'s 1971 foundational collection of the same name in which Karenga's essay was published - was at first glance a project dedicated to the identification and celebration of a universal, unchanging cultural core of blackness. In fact, however, the black aesthetic always contained within it a sense of motion, of movementtoward. Julian Mayfield, in his contribution to Gayle's anthology, envisioned an unchanging blackness when he described the black aesthetic as that "which cannot be stolen from us" because it "is in our racial memory" (Mayfield 27). A single page later, however, Mayfield offered a very different vision: "The Black Aesthetic, if it is anything, is the search for a new program. . . It is the search for a new spiritual quality, or the recapture of an old one, lost and buried deep in our African past" (Mayfield 28; emphasis added). The search for the newly created oscillates with a search for the old and unchanging (one search or the other, not one and the other). Members of the BAM, including Nikki Giovanni, developed a complex theory of movement-bodily movement, mass movement-toward, and what Kimberly Benston calls the "polymorphic movements of 'blackness" " - as a political tool and source 
of power (3). Addison Gayle, Jr., makes this point in the epigraph to this essay: in the black aesthetic, Gayle writes, "each act, gesture, and movement is political" (qtd. in Bigsby). Houston Baker's often quoted comment on sound is equally a comment on bodily motion: "The spirit evoked by the Afro-American modernists is an eternally transformative impulse that converts desire not only into resonant and frequently courageous sound but also into ceaseless motion" (Smith 354; emphasis added). This theory of black arts not only as $a$ movement but literally as movement co-existed with demands for unification around stable black identity. The latter, in the view of Baraka

\section{In a community on the verge of xenophobic factionalization, "we" is a potentially dangerous concept.}

and others, ran the BAM aground in the mid-seventies, but a strategic concept of black politics and aesthetics as movement, as what Diana Taylor would call repertoire, survived.

During and beyond the years of the BAM, Nikki Giovanni affiliated herself with the motional rather than the stabilizing aspects of the BAM by unambiguously rejecting attempts to identify an unchanging black aesthetic. In 1972, when a reporter asked, "How would you define a black esthetic?" Giovanni answered bluntly, "I don't," because that endeavor is "a waste of time" (Terrell 46). In an autobiography published the same year as The Black. Aesthetic, Giovanni again rejected the notion of a singular black aesthetic in favor of plural, community-based visions: "We hear a lot about the Black aesthetic," she wrote. "The aesthetic is the dream a culture wishes to obtain. .. . [W] are our aesthetic" (Giovanni, Gemini 125).

Acknowledgment of these contradictory impulses within the BAM challenges the too-common assessment of the BAM as a failure. ${ }^{3}$ Lorrie Smith was right when she recently observed that the BAM's black aesthetic was neither "a programmatic set of precepts doomed to fail," nor, in Horace Coleman's incendiary term, "a cement 'straitjacket' limiting freedom of expression," but was instead a set of "multiple, rhizomatic, enabling practices that redirected the course of black poetry and that continue to be enacted in enormously diverse and diffuse ways" (Smith 359; emphasis added). These practices remained available for Nikki Giovanni to enact in her and her community's moment of need.

Giovanni, speaking in the register of the BAM that she co-created, understood the precarious, terrifying moment in Virginia Tech's history as a "wheel spinning," and she said that her goal was "to find a way to let that motion carry us forward" (Browning). She attempted to reach this goal with a poem that repeated two lines: "We are Virginia Tech" and "We will prevail."4 These lines, as the centerpiece of the poem, became devices by which to redirect the wheel of Virginia Tech. According to many witnesses, the lines had precisely that effect. Ishwar Puri, a professor of engineering science and mechanics who was present in the Coliseum on April 17, described Giovanni's poem as "the turning point, at least for me. I suppose it gave us a few phrases to hang on to. 'We are Virginia Tech. We will prevail.' I can't overemphasize the importance of that moment" (Lazenby 124). Student-made T-shirts reading "We are Virginia Tech" swiftly appeared "everywhere on campus" and raised over $\$ 200,000$ for the Hokies Spirit Memorial Fund (Dewan and Sabar, Nickel, Macy). 5

In a community on the verge of xenophobic factionalization, "we" is a potentially dangerous concept. The concepts of "we" and "they" define each other and define lines of difference. The physical setting of the Coliseum magnified this danger 
because it is a space that Marvin Carlson would describe as "haunted" by the ghosts of past sports rivalries, a sense of the home team's "we" versus an outsider "they" (Carlson). In sports, such competitions routinely spark violence from on-court scuffles to parking lot riots. The "we" of sports is an exceptionally volatile "we." But the "we" of sports has another aspect - one based on vicarious identification. As Jerry Seinfeld humorously observes, sports fans leave an arena cheering "We won!" when in fact, "they won, you watched" (qtd. in Marqusee 11). It is the ability to identify with others that defines rooting and enables pleasurable sports spectatorship. Giovanni, a sports fan, was aware of both these practices, of both these potentials that hover, perennially, in every sports arena.

In a virtuoso act of brinksmanship, Giovanni dared all present to practice the bodily felt identification with others so familiar within the space of the Coliseum, but to do so without opposition to any rival. Her poem linked the tragedy at Virginia Tech to geographically remote but equally painful losses: "a child in Africa dying of AIDS," a "baby elephant watching his community being devastated for ivory," and "invisible children walking the night away to avoid being captured by the rogue army." 6 In this moment of intense suffering, when so many promoted fear and insularity by speaking in polarizing terms of good people victimized by bad people (as President Bush did in his address at the Virginia Tech Convocation, when he quoted Romans 12:21: "Don't be overcome by evil, but overcome evil with good"), Giovanni reminded her community of the universality of tragedy, which "no one deserves." " Her vision stretched across differences of nation and continent, of age, and even of species. Giovanni's "we" was local— "We are Virginia Tech" - but simultaneously connective and relational: "The Hokie Nation embraces our own and reaches out with open heart and hands to those who offer their hearts and minds." The "we" of Virginia Tech, the "we" who will prevail, is an expansive, capacious "we," a "we" that quietly disintegrates the binarized "they." It is a utopian configuration: a "we" without a "they."

Giovanni wrote with a sense of a wheel already in motion, a wheel whose energy it was her job to capture and redirect. And the poem itself contains a sense of a demand: as journalist Maria Browning noted, "We Are Virginia Tech" is "more exhortation than elegy" (Browning). But exhortation to what? The poem describes some actions in a constative mode: Hokies, the poem tells us, are and will continue to be sad, to mourn, and to embrace each other within and beyond the community. In a performative mode, however, the poem's key lines, "We will prevail" and "We are Virginia Tech," echoed in the Coliseum as exhortations. The line "We are Virginia Tech" is not merely descriptive; it is a performative utterance, as much so as the delivery room proclamation, "It's a girl" (Butler 232). The line and the poem of the same title performatively demanded immediate, collective response. Giovanni's aesthetic, built over forty years, is unbounded, forward-moving, and embodied: "[T]he aesthetic is the dream a culture wishes to obtain," she wrote in 1971, "we are alive to the imaginations and the possibilities/We will continue to invent the future," she continued in 2007. In 1971, "We are our aesthetic"; in 2007, "We are Virginia Tech."

And the audience answered Giovanni's call. Upon the poem's closing lines, which repeated yet again the two key phrases, the overcapacity audience in Cassell Coliseum immediately stood up and applauded thunderously. The mass gesture of standing was almost instantaneous: immediately after the close of Giovanni's poem, CNN's live cameras swept across the audience, which was already on its feet. The videotape shows almost no individuals in the act of standing up_-almost all, including George Bush, are standing within a split second of Giovanni's conclusion. This timing is significant because it demonstrates that the standing ovation was not the sort in which some people begin to clap while sitting, and then, upon seeing others rise, choose-perhaps reluctantly_also to rise. Rather, as the CNN footage clearly shows, the entire audience, as one, stood and applauded. 
After a fifty-four-second standing ovation, the crowd, still standing, spontaneously began chanting "Let's go, Hokies!" Each repetition of this sports cheer was followed by five rhythmic claps; the audience completed the cycle of chanting and clapping nine times in twenty-five seconds. The chanting, especially in the later repetitions, was urgent and intense, and was followed by more cheering. By the end, the audience had stood, cheering and chanting and then cheering again, for more than ninety seconds.

According to many witnesses, Giovanni's performance of "We Are Virginia Tech" and the audience's performance of "Let's go, Hokies!" together transformed the campus's energy and "brought together a heterogeneous campus" (French). One journalist described the two-part performance as "jarring, inspiring, and deeply moving, all at once" (Browning). Brittney Asbury, a student, called Giovanni’s performance

the most powerful and moving speech I have ever heard, and as long as I live, I will never forget what happened next. In the midst of the most trying times, I stood with eleven thousand of my fellow Hokies and with tears streaming down my face chanted "Lets [sic] Go Hokies." I didn't know whether to smile or cry. (Lazenby 123-24)

Another student, Kevin Cupp, said that Giovanni's poem in combination with the audience's chant changed the course of events. Immediately after the chant, Cupp said to a companion, "Wow, we really needed that." He later explained,
All of the speeches before her [Giovanni] were about how we had lost fellow Hokies and how we'd always remember them. While those words were necessary to say, Nikki Giovanni's speech was the perfect closing speech to really show what the Hokie spirit was all about. I couldn't help but start laughing during the 'Let's Go Hokies' chant; not that it was funny, but it was just such an overwhelming change of mood and sense of Hokie spirit. (Lazenby 124; emphasis added)

The New York Times similarly identified Giovanni's poem as "an emotional turning point in that ceremony, bringing a somber crowd to its feet" (Urbina). Virginia Fowler, who is not only Giovanni's partner, but also the scholar who has published most extensively on Giovanni's work,

credits Giovanni with defining the community's response to the tragedy: "It sort of set the tone for how the university was going to deal with it," says Fowler. "Her speech really did give the university a direction, a way of responding to something that had pretty much overwhelmed everyone." (Browning; emphasis added)

Nikki Giovanni said she intended to shape and redirect large-scale motion at Virginia Tech, but there is no evidence that she consciously aimed to provoke the chant "Let's go, Hokies." 8 When Giovanni entered the Coliseum on April 17, however, she did so as a sports fan with expertise in practices of athletic spectatorship. She knew the Coliseum's ghosts. Long before the shooting, Giovanni had recognized the danger that Cho presented because, in her words, her business as a poet is to "deal in emotional knowledge"; and in the Coliseum, Giovanni literally mobilized her emotional and experiential knowledge of sports spectatorship in general and Hokies athletics in particular. 'The properties of "We Are Virginia Tech"-its sloganlike repetitions, its plain and transparent phrasing, its absence of even one metaphormirror the qualities of a sports chant (a writer for the Guardian even called "We Are Virginia Tech" a "chant poem") (French). The poem is not merely accessible; it is, in its invocation of innocent babies, children, and even baby animals, entirely too sentimental. Giovanni initially considered the poem "pedestrian," and it was indeed pedestrian in the sense that it was designed for ambulation, for commonplace, forward-moving embodiment. It is a hook, a call to action. The plain literalism of Giovanni's words mirrored the plain literalism of a sports chant, and this mirroring enabled the poem to draw forth the emotional depth, nuance, richness, and vitality that Giovanni, as sports fan and poet, knew lay nascent in every sports cheer. Giovanni drove the bus. Raising the ghosts of past acts of sports spectatorship 
and drawing on theories and practices of the BAM — which she had co-createdGiovanni took a wheel spinning and found a way to let that motion carry her community forward. As one witness put it, "Her words were poetry in motion" (Swint).

After the Convocation, racist and xenophobic reactions to the mass murder were milder than many people had feared. The audience that responded to Giovanni's exhortation, the community that restored and transformed the gestures of sports spectatorship to perform a "we" without a "they," later collectively rejected xenophobia in favor of a fervently repeated (and even physically worn) refrain of "We are Virginia Tech." The afternoon Convocation's chant of "Let's go, Hokies" continued at a candlelight vigil that evening, and participants connected that chant to the one in the Coliseum: as student Tricia Sangalang observed, "Students yelled, 'Let's Go!' Just like at the Convocation hours before, a thunderous sound echoed through the crowd in response: 'Ho-kies!' "' (Lazenby 131; emphasis added).

It is of course impossible to prove that Giovanni's and the audience's performance at the Convocation directly prevented violence. ${ }^{10}$ Even without proof of causality, however, a few facts are clear: at the bottom of hell, Nikki Giovanni ignited a mass performance of utopia. And she did it queerly, as a black woman poet wearing a men's tie.

\section{Punking the President}

B efore Giovanni stepped onto the floor of the Coliseum, she revised the poem she wrote the previous night only by deleting one line: from the list of those who do not deserve a tragedy, she crossed out "the Iraqi teenager dodging bombs" ("We Are" 108). ${ }^{11}$ Giovanni temporarily eliminated the line, which she would later reinstall in the published version of the poem, for one reason: she knew that the president who ordered those bombs would be in the audience. The radical poet who had fearlessly eviscerated every president from Johnson through, now, Obama (who earns, in her assessment, "maybe a D plus" as president [Browning]), was suddenly principally concerned with angering George W. Bush. As she stepped forward to read her poem, one thought filled her mind: "Please, dear God, don't let me punk the president off" (Macy).

Giovanni's choice in this moment could be read as cynical self-interest, a political concession, or perhaps a late-life mellowing, or even capitulation from a poet known to be fearlessly confrontational. More generously, perhaps, Giovanni's self-censorship might seem like a compromise, a temporary putting-aside of partisan politics for the purpose of community healing. One factor, however, interrupts all these interpretations. Giovanni's sartorial choices-her men's necktie and suit in a masculine cut-counterevidence a desire to avoid confrontation. Had Giovanni simply wanted to avoid controversy, she could have left her tie home. (While the tie is her "trademark" [Macy], she does make public appearances without it; she is tieless in, for example, the photograph on the 2003 cover of The Prosaic Soul of Nikeki Giovanni.)

Giovanni's queer appearance in the Coliseum attracted notice and comment: as one journalist understated, "with her close-cropped hair and masculine suit and tie, she must have cut a surprising figure to many of the people across the country who watched the ceremony on television" (Browning). Twenty-four hours after a mass murder, on a campus eager to create racialized scapegoats, Giovanni summoned the ghosts of sports rivalries, the practices of spectatorship that create sometimes violently clashing "we" and "they," and she sartorially intensified her own brinksmanship: she risked creating a unified "we" that could have cast her in the perilous role 
of "they." Giovanni risked the audience in the Coliseum turning on her as the black dyke who recognized Cho's madness, but failed to prevent the mass murder.

Giovanni's outfit warrants close analysis for two reasons. First, Giovanni has, since the 1960s, cultivated a visually striking self-presentation that has changed over time but that has consistently been consciously meaningful. As an undergraduate at Fisk in the early 1960s, Giovanni was "dismissed" for insubordinations that reportedly included wearing pants (Giovanni was later readmitted to Fisk and graduated in 1967). ${ }^{12}$ In the late sixties, Giovanni and many others visually asserted Black Power politics by wearing a large Afro_-one that, in Giovanni's case, seemed even larger in proportion to her diminutive body (in 1969, Mae Jackson described Giovanni as "a real fine-looking sister" who "weighed 100 pounds, and that was with her machine gun on" [85]). ${ }^{13}$ During the 1990s, Giovanni adopted masculine clothing and very short hair, which she has often kept bright platinum. For at least forty years, then, Giovanni has styled herself for visual and political impact.

Second, Giovanni chose her outfit — collared shirt, men's tie, and crew cutamong many possible ways for a woman, particularly a black woman, to perform masculinity. In other words, Giovanni could have made an equally strong statement of gender-queerness or masculinity without any of these clothing elements. The diverse forms of female masculinity, especially among women of color, prompted B. Cole recently and influentially to coin the phrase "masculine of center" or MOC. This phrase aims to describe "the cultural breadth and depth of identity for lesbian/ queer womyn who tilt toward the masculine side of the gender scale" and to function as a term that is "more encompassing and less racially and class-specific than butch" (Cole 128). ${ }^{14}$ Cole lists a range of terms that MOC women, especially those of color, may self-assign: "butch, stud, aggressive/AG, tom, macha, boi, dom, etc." (128). That "etc." includes "dapper" or "dapper boi," a term that many black and nonblack women have recently adopted ("dandy" or "all-American" describe nuances within this mode of self-presentation). Giovanni self-styles in a dapper mode when she dons a tie, white shirt, and masculine suit.

Dapper self-presentation contrasts with the many forms of female masculine performance that are inspired by (and part of) hip hop fashion, and that contrast can help unpack the ways in which dapper couture constructs meaning. Dapper and hip hop-inspired fashions cover and reveal the body in different ways. Hip hop fashion can obscure the body with oversized pants and shirts, but those same clothing items can expose a good deal of skin. For example, pants may be simultaneously oversized and cropped to expose calves, and a shirt may be simultaneously oversized and sleeveless. The dapper look, in contrast, flashily displays sexuality through the covering of the body: the closed cuff, the buttoned collar. A mode of MOC flamboyance, dapper styling is a loud, even exhibitionistic statement of gender and sexuality that attracts attention while it deflects it and announces gender-queerness while it protects female skin from scrutiny. ${ }^{15}$

Giovanni's sartorial choices at the Convocation are important because they provide a model by which to understand her editorial ones: in both her self-presentation and her writing, Giovanni has long interlaid exhibitionism and self-protective covering. Since the late 1960s, Giovanni has been criticized for being both outrageously confessional (many in the BAM were horrified when Giovanni's poems began to focus on personal experience rather than political calls to arms), but also intensely private (for example, Giovanni has consistently declined to identify the father of her son who was born in 1969). While Giovanni has not publicly discussed her relationship with Virginia Fowler, she and Fowler have, in a well-publicized and celebrated move, bequeathed their shared estate, including the rights to Giovanni's creative work, to Virginia Tech. ${ }^{16}$

Clothing coordinates with other practices of meaning-making, and it also shapes behavior, including the potentially unruly behaviors of sports spectatorship —as 
Giovanni acknowledged when she suggested, in what can only be called a vision of a queer athletic utopia, that "everyone be required to wear a tie to sporting events" because "well-dressed people behave better" (Fishman). Dapper self-presentation shapes behavior by directing and redirecting attention: the necktie attracts the gaze to the clothes but then prevents the gaze from penetrating to the skin. Giovanni summoned these skills in her engagement with her audience and its most prominent member: the President of the United States. As Giovanni's outfit showed by hiding and hid by showing, so too did her poem manage and direct attention through its silences as much as through its words.

As Giovanni stepped up to the podium at the Convocation, she made eye contact with Bush, who earlier had delivered his own address to the Virginia Tech community. The poet and the president nodded to each other (Macy). As Douglas Kellner has shown, Bush brought his own political agenda to the Convocation. The murders at Virginia Tech occurred at a tenuous moment in the Bush presidency: the Democrats had just gained a majority in both the House and the Senate, and after four years of war, a majority of Americans had grown to oppose Bush's Iraq policy. Kellner argues persuasively that Bush hoped to use the Virginia Tech Convocation as a media opportunity by which to crown himself "Mourner-in-Chief," and thus raise political capital similar to that which he accrued after September 11, 2001.

Had Giovanni spoken the line about the Iraqi teenager dodging Bush's bombs, she would have risked the audience turning its attention from her to Bush. We can imagine, at that moment, the CNN camera swinging from Giovanni to a tight shot on Bush's face, his mouth in a thin line or smirk. This redistribution of attention would have transformed the event from a utopian performative that constructed a "we" without a "they" into a cheap smackdown between an queer black firebrand and a respectfully mournful icon of America itself. In such a competition, Giovanni surely would have lost. But instead of competing with the president, Nikki Giovanni, in an act of strength, style, and self-determination that exemplifies the best of the Black Arts Movement, eclipsed him.

Giovanni's choice to silence temporarily the line about Iraq was neither a compromise nor a concession, but was instead a dapper political move that prevented Bush from using the Convocation to reconsolidate his own power. By temporarily eliminating the line, Giovanni masterfully manipulated and managed attention; she kept the gaze on herself (thus making unnecessary a CNN camera-cut to Bush) and not on the President. Beside Giovanni's poem, Bush's speech paled, receiving only a fraction of the media commentary that Giovanni's performance garnered. Giovanni prayed to avoid punking, the President off, and it was exactly this avoidance that enabled Giovanni to punk, or snooker him. As the audience filed out of the Coliseum, the president said to the gender-queer black poet the only available thing: "Good job" (Macy).

\section{A "We" without a "They": The BAM and Utopian Performatives}

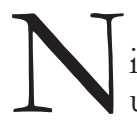
ikki Giovanni's and the audience's co-creation of a "we" without a "they" ultimately adjusts understanding of key elements of both the BAM and the concept of utopian performatives, and this adjustment enables the strengths of each to show more clearly. As Larry Neal and other members of the BAM have argued, the goal of artistic self-determination functioned as a call to obliterate double consciousness and to create a self-interpreting arts community. ${ }^{17}$ This ongoing project was realized at the Virginia Tech Convocation when Giovanni drew upon and transformed the practices of sports spectatorship to create a "we" without a "they"- 
that is, when Giovanni and the audience performatively disintegrated the systemically imposed sense of racial otherness that is the basis for double consciousness. The utopian moment was not one in which the audience transcended race. ${ }^{18}$ Rather, it was one that disabled the practice of othering — and with it, the conditions for double consciousness. The performance in Cassell Coliseum fulfilled this important goal of the BAM not by burning a white perspective out of black consciousness, but instead by short-circuiting, through restored movement, the ability of non-Asian Americans, including white and black members of the Virginia Tech community, to imagine a racial other. Under Giovanni's leadership, the audience in the Cassell Coliseum united through coordination rather than homogeneity-and this accomplishment was indebted to and therefore should be understood as a successful extension of the BAM.

The performance at the Convocation also resolves potential challenges to the important concept of the utopian performative as theorized by both Jill Dolan and José Esteban Muñoz. For Dolan, "utopian performatives describe small but profound moments in which performance calls the attention of the audience in a way that lifts everyone slightly above the present, into a hopeful feeling of what the world might be like if every moment of our lives were as emotionally voluminous, generous, aesthetically striking, and intersubjectively intense" (Dolan 5; emphasis added). Dolan's concept of a utopian performative is based on unitary feeling- the necessity of "everyone" feeling the same thing at the same time. This insistence risks reproducing the Achilles heel of the BAM itself, which crumbled, in Baraka's view, because "black" is not, in fact, a unifying ideology. Furthermore, this concept of utopian performatives raises a problem of evidence: how is a scholar to know how "everyone" feels? What constitutes proof that one feeling suffuses all present and that therefore a utopian performative has occurred? Muñoz, in contrast, understands utopia and queerness itself as always in the future, always on the horizon: utopia is, for Muñoz, "an insistence on something else, something better, something dawning"; and queer "aesthetic and political practices" can "be seen as necessary modes of stepping out of this place and time to something fuller, vaster, more sensual, and brighter" (Muñoz 189). For Muñoz, utopia is a "temporal disorganization," a "moment when the here and now is transcended by a then and a there" (97). But Giovanni understood her task at the Convocation - and her very identity as a poet - to be defined through the present: when asked to explain how she conceived "We Are Virginia Tech," she said that her "job is to be in the moment." In contrast, as Muñoz defines utopia, it cannot swell in the present; indeed, a Muñozian utopia is an evacuation of immediate, pragmatic goals. Also, whereas Muñoz rejects antirelationality but stops short of embracing relationality, Giovanni based her vision in relationality, especially through the experience of tragedy as shared across continentsand the performance in the Coliseum enacted utopia through relationality, through synchronized movement and identification across difference. Taken together, then, Dolan might seem too quick to declare the presence of utopian performatives and Muñoz might seem too quick to disallow for their immediate presence, practicality, and basis in relationality.

My point is not that Giovanni's performance disproves either Dolan or Muñoz, but rather that the events in the Coliseum prove Dolan and Muñoz fundamentally correct, even beyond their own claims: a Dolanesque utopian performative is best evidenced through audiences not feeling as one but moving in synchronicity, and a Muñozian utopia that emerges through relational movement can, in fact, crack the barrier between future and present to achieve immediate, practical, and profound effects. Nikki Giovanni's performance, as it extends and enacts theories of the BAM while avoiding its pitfalls, points toward new possibilities in the study of utopian performatives and affect studies most broadly: a focus on bodies not only feeling but moving in concretely observable ways allows for discussions of coordination where it exists - and no more. This approach does not depend on the inference 
of unified feeling, and therefore enables scholars to analyze a heterogeneous group of people (such as African Americans or the audience at the Convocation) without generalizing in ways that erase differences. If scholars of affect take a cue from Giovanni and the BAM, we will find potential not only in what Eve Kosofsky Sedgwick called touching feeling, but in touching feeling moving.

On April 17, 2007, over ten thousand people did not only feel or glimpse a better world - they created it. They moved in unison not only to applaud a black masculine feminist poet but to remake themselves in her image, to reinvent a sports cheer as a poem and themselves as poets, and to enact a heterogeneous "we" with no racialized "they." That utopian moment was not fleeting, but rather, long-lasting: of the ten thousand people who chanted in Cassell Coliseum, some-George W. Bush, for example-may leave forever, but others will return to the Coliseum for Hokies basketball. Perhaps some will wear T-shirts repeating lines from Giovanni’s poem. When basketball fans now chant "Let's go, Hokies" in Cassell Coliseum, some restore, with their hands and mouths, the gestures of the utopian moment that those individuals once performed in the same space. Certainly this restoration will last through the graduating Class of 2011. Even after these students have left, however, alumni, as well as faculty, administrators, and staff, have also returned. Twenty years from now, one of the ten thousand present at the Convocation-perhaps Giovanni, perhaps an alumna, perhaps a janitor who swept up after that event-will attend a game in Cassell Coliseum, and will chant "Let's go, Hokies" as at once sports cheer and poem. Thus will a utopian moment, as with a wheel turning, spin into a better future.

Performance studies claims, as a central tenet, that meaningful gestures possess both a very long half-life and the ability to transfer from person to person. The utopia enacted in Cassell Coliseum through mass movement was anything but fleeting, anything but local: as the Convocation continues to transmit through the airwaves, through the Internet, through the bodies of those present, the reality of a "we" without a "they" that was performed on one day and in one place ripples in endless, concentric circles out from Cassell Coliseum and into the future. We are Virginia Tech. Let's go, Hokies.

I thank Renée Bergland, Soyica Diggs Colbert, Margo Natalie Crawford, Betsy Klimasmith, and an anonymous reviewer for their insightful comments on this essay.

1. For contexts and extensive details of the attacks, see The April 16 Archive and Mass Shootings at Virginia Tech, April 16, 2007: Report of the Virginia Tech Review Panel Presented to Timothy M. Kaine, Governor, Commonwealth of Virginia, August 2007, Web. Personal testimony by witnesses and survivors appears in Lazenby. Scholarly essays, mostly from a social science or media studies perspective, are collected in Agger and Luke. Roy, a professor at Virginia Tech who tried valiantly from 2005 to convince Cho to seek counseling, recollects, contextualizes, and analyzes the events in No Right to Remain Silent: The Tragedy at Virginia Tech. I order the shooter's family and given names in the custom of the United States rather than Korea as per the preference of his parents (Roy 2).

2. Nikki Giovanni is today generally considered a feminist poet, but her relationship to feminism is complex and has changed over time. In the early 1970s, Giovanni frequently criticized feminism, which she considered to be a white women's movement (Fowler 12-13, 62).

3. The most famous assessment of the BAM as a failure is that of Henry Louis Gates, Jr., who characterized the BAM as the shortest and least artistically successful "renaissance" in black literature (Gates).

4. Video of Giovanni's performance, and a transcript of the poem as she read it are online at CNN.com and the April 16 Archive, respectively.

5. Nickel shows how Giovanni's other key phrase, "we will prevail," was repeated in administrative e-mail in the week following the Convocation; see Nickel 161-62.

6. Except where otherwise specified, all quotations from Giovanni's performance of "We Are Virginia Tech" are transcribed from CNN video.

7. Bush's Convocation address is online in many locations, including YouTube. 
8. After the chanting started, Giovanni did urge the crowd on by pumping her hand in rhythm.

9. On Giovanni's sports fandom, see Macy. The same year that Giovanni performed in the Coliseum, she published Acolytes, a collection of poetry and prose that includes a brief piece, titled "Letter to the Editor," decrying a local television station's choice not to air a particular Hokies football game (Giovanni, Acolytes 83-84).

10. For other possible causes, see Roy 266-67. For a very different assessment of Giovanni’s performance and the audience's response, see Nickel.

11. The poem as published in Bicycles differs in many small ways from the poem Giovanni recited at the Convocation. Most of the revisions tighten the poem: for example, the spoken "neither does the Appalachian infant killed in the middle of the night in his crib in the home his father built with his own hands being run over by a boulder" becomes, in the printed version, "Neither does the Appalachian infant killed / By a boulder / Dislodged / Because the land was destabilized" (108). The only significant addition to the printed version is the line about the Iraqi teenager, which Giovanni told a journalist she wrote before the Convocation but chose not to speak aloud (Macy).

12. Giovanni has said that she was dismissed from Fisk because she left campus without permission and because her "attitudes did not fit those of a Fisk woman" (qtd. in Murphy 109). However, Jessie Carney Smith, a librarian at Fisk during Giovanni's undergraduate years, told a journalist that Giovanni was expelled "for defying policies she considered unreasonable_-including, according to Smith, a rule forbidding female students to wear pants" (Browning).

13. I thank Margo Natalie Crawford for drawing my attention to this quotation.

14. B. Cole is the founder and Project Director of the Brown Boi Project, and has been a foundational influence on and participant in the annual conference, Butch Voices. Both the Brown Boi Project and Butch Voices focus on masculine women and transgendered people of color.

15. In a black context, dapper styling both adheres to and defamiliarizes the politics of respectability, while hip hop styling, in contrast, challenges the politics of respectability. Dapper and hip hop-inspired modes of gender performance are not mutually exclusive: indeed, in the Coliseum, Giovanni's dapper suit covered a tattoo on her arm that reads THUG LIFE. The tattoo, which Giovanni got in memory of Tupac Shakur (she also has a large poster of Shakur in her office at Virginia Tech, and she dedicated her 1997 book Love Poems to the rapper), permanently aligns the poet with hip hop masculinity (on Giovanni's admiration for Tupac Shakur, see French; Macy; and Calvin Reid, "Nikki Giovanni: Three Decades on the Edge," Publishers Weekly 245.26 [28 June 1999]: 46-47). These connections were not visible, however, on April 17. What audiences in the Coliseum and on CNN saw was Giovanni's dapper styling, which attracts the gaze through visually striking gender transgression and then limits that gaze by refusing to display skin.

16. Giovanni's and Fowler's gift will fund "The Answer is Yes: Fowler-Giovanni English Department Program Endowment." See Tonia Moxley, "Poet Nikki Giovanni to Bestow Copyrights to Tech," Roanoke Times, 30 Apr. 2010, Web; and "University Announces Gift of Fowler-Giovanni Fund," Virginia Tech News, 30 Apr. 2010, Web. Virginia Tech publicly celebrated Giovanni's and Fowler's gift; video of that celebration is online at http://www.unirel.vt.edu/audio_video/answer-is-yes.html. Giovanni and Fowler discussed their home and garden in an article in a local newspaper in 2008 (Wolfe). Giovanni has not publicly described herself as a lesbian, but in 2008, Curve magazine included Giovanni on list of "Powerful Lesbian Academics" (Pepper), and Giovanni has not publicly objected to this designation.

17. In his afterword to Black Fire, Neal identified the destruction of double consciousness as that book's principal theme. "Most contemporary black writing of the last few years, the literature of the young," Neal wrote, "has been aimed at the destruction of double-consciousness," and thus "consolidating the African-American personality" (647). On the BAM's goal of destroying double consciousness, see also Soyica Diggs Colbert, The African American Theatrical Body: Reception, Performance, and the Stage (New York: Cambridge UP, 2011), 198, and Benston in passim.

18. For a trenchant critique of claims of racial transcendence, see Brandi Wilkins Catanese, The Problem of the Color[blind]: Racial Transgression and the Politics of Black Performance (Ann Arbor: U of Michigan P, 2011).

Works Agger, Ben and Timothy W. Luke, eds. There Is a Gunman on Campus: Tragedy and Terror at Virginia Tech.

Cited New York: Rowman \& Littlefield, 2008.

The April 16 Archive: Collecting and Preserving Memories of the Virginia Tech Tragedy. Center for Digital

Discourse and Culture, Virginia Tech University. Web. 15 Apr. 2012.

Baraka, Amiri "Black Fire: A New Introduction" Baraka and Neal xvii-xx.

--, and Larry Neal, eds. Black Fire: An Anthology of Afro-American Writing. 1968. Baltimore: Black Classics, 2007. 
Benston, Kimberly W. Performing Blackness: Enactments of African-American Modernism. New York: Routledge, 2000.

Bigsby, C. W. "Black Arts Movement: An Interpretation." Africana: The Encyclopedia of the African and African American Experience. $2^{\text {nd }}$ ed. Eds. Kwame Anthony Appiah and Henry Louis Gates, Jr. Web. 12 Apr. 2012.

Browning, Maria. "Employed by Truth: Poet Nikki Giovanni Is Still Speaking her Mind." Chapter 16: A Community of Tennessee Writers, Readers \& Passersby. 24 Feb. 2010. Web. 15 Apr. 2012.

Butler, Judith. Bodies that Matter: On the Discursive Limits of "Sex". New York: Routledge, 1993.

Carlson, Marvin. The Haunted Stage: The Theatre as Memory Machine. Ann Arbor: U of Michigan P, 2001.

Cole, B. "Masculine of Centre, Seeks Her Refined Femme." Persistence: All Ways Butch and Femme. Eds. Ivan E. Coyote and Zena Sharman. Vancouver: Arsenal Pulp, 2011. 127-36.

Dewan, Shaila, and Ariel Sabar. "At Virginia Tech, Remembering While Moving On." New York Times 20 Aug. 2007. Web. 12 Apr. 2012.

Dewan, Shaila, and John M. Broder. "Two-Hour Delay is Linked to Bad Lead." New York Times 18 Apr. 2007. Web. 28 Mar. 2012.

Dolan, Jill. Utopia in Performance: Finding Hope at the Theater. Ann Arbor: U Michigan P, 2005.

Fernandez, Manny, and Marc Santora. "Gunman Showed Signs of Anger." New York Times 18 Apr. 2007. Web. 28 Mar. 2012.

Fishman, Kathryn. "Preparing for Mars: Reflections on Nikki Giovanni." The Missouri Review [Blog]. February 2005. Web. 15 Apr. 2012.

Fowler, Virginia C., ed. Conversations with Nikki Giovanni. Jackson: UP of Mississippi, 1992.

French, Philip. "In Praise of Nikki Giovanni." Guardian 21 Apr. 2007. Web. 12 Apr. 2012.

Gates, Henry Louis, Jr. "Black Creativity: On the Cutting Edge.” Time 144.15 (10 Oct. 1994): 74-75. Web. 12 Apr. 2012.

Gayle, Addison, Jr., ed. The Black Aesthetic. Garden City, NY: Doubleday, 1971.

Giovanni, Nikki. Acolytes. New York: William Morrow, 2007.

-. Gemini: An Extended Autobiographical Statement on My First Twenty-five Years of Being a Black Poet. 1971. The Prosaic Soul of Nikki Giovanni. New York: Perennial, 2003. 169-90.

—-. "We Are Virginia Tech (16 April 2007)." Bicycles: Love Poems. New York: William Morrow, 2009. 107-09.

Jackson, Mae. "I Remember Omar.” Negro Digest 18.8 (June 1969): 83-85. Google Books. Web. 28 Mar. 2012.

Karenga, Ron. "Black Cultural Nationalism." Gayle 32-38.

Kellner, Douglas. "Media Spectacle and the 'Massacre at Virginia Tech.' " Agger and Luke 29-54.

Lazenby, Roland, ed. April 16 $6^{\text {th }}$ Virginia Tech Remembers. New York: Plume, 2007.

Luke, Timothy W. "April 16, 2007, at Virginia Tech-To: Multiple Recipients: 'A Gunman Is Loose on Campus. ..." " Agger and Luke 1-28.

Macy, Beth. "Nikki Giovanni: Unlikely Ambassador." Roanoke Times 19 Aug. 2007. Web. 28 Mar. 2012.

Marqusee, Mike. Redemption Song: Muhammad Ali and the Spirit of the Sixties. London: Verso, 1999.

Mayfield, Julian. "You Touch My Black Aesthetic and I'll Touch Yours." Gayle 24-31.

Muñoz, José Esteban. Cruising Utopia: The Then and There of Queer Futurity. New York: New York UP, 2009.

Murphy, Frederick D. "Nikki." 1975. Fowler 104-12.

Neal, Larry. "An Afterword: And Shine Swam On." Baraka and Neal 637-56.

Nickel, Patricia Mooney. "There is an Unknown on Campus: From Normative to Performative Violence in Academia." Agger and Luke 159-84.

Pepper, Rache[1]. "Powerful Lesbian Academics." Curve 18.2 (February 2008). Web. 15 Apr. 2012.

Roy, Lucinda. No Right to Remain Silent: The Tragedy at Virginia Tech. New York: Harmony Books, 2009.

Sedgwick, Eve Kosofsky. Touching Feeling: Affect, Pedagogy, Performativity. Durham: Duke UP, 2003.

Smith, Lorrie. "Black Arts to Def Jam: Performing Black 'Spirit Work' Across Generations." New Thoughts on the Black Arts Movement. Eds. Lisa Gail Collins and Margo Natalie Crawford. New Brunswick, NJ: Rutgers UP, 2006. 349-68.

Swint, Christine. "Mariacristina Blog Archive for Virginia Tech, 20 April 2007." The April 16 Archive. 25 May 2007. Web. 15 Apr. 2012.

Terrell, Angela. "Nikki Giovanni: 'Vision and Space.' " 1972. Fowler 43-48.

Urbina, Ian. "Tears are Mixed at Virginia Tech Commencement." New York Times 12 May 2007. Web. 12 Apr. 2012.

Wolfe, Libba. "Friendly Garden Tour in the New River Valley." Roanoke Times 5 July 2008. Web. 12 Apr. 2012. 